\title{
Chimeric Heterosis for Body Weight in Mice
}

Akira ONISHI and Hitoshi MIKAMI

National Institute of Animal Industry Tsukuba Norindanchi, Ibaraki-ken 305

(Received July 15, 1986)

\begin{abstract}
We confirmed chimeric heterosis for body weight in chimeric mice and examined the relationship between heterosis and the relative proportions of two cell populations in their bodies. Aggregation chimeras were made from embryos of $\mathrm{C} 57 \mathrm{BL} / 6$ and $\mathrm{BALB} / \mathrm{c}$ mice. Chimeras and control animals, C 57 $\mathrm{BL} / 6, \mathrm{BALB} / \mathrm{c}$ and their reciprocal $\mathrm{F}_{1}$ crosses, were weighed at 8 weeks of age. The mean body weight of chimeras was significantly larger than that of the two inbred strains, and chimeric heterosis for body weight was clearly identified as $16.4 \%$ in males and $11.9 \%$ in females. Heterosis averaged in the reciprocal $F_{1}$ crosses was $19.3 \%$ in males and $11.5 \%$ in females. In the chimeras, proportions of cells from each component strain were estimated by quantitative GPI analyses, using 10 organs (liver, kidney, spleen, stomach, intestine, lung, heart, erythrocyte, testis or ovary and seminal vesicle or uterus). The slight high percentage of BALB/c cells was observed in the mean cell proportions of organs. The linear regression of body weight on degree of chimerism was statistically significant in males $(b=-0.083 \pm 0.019)$ and in females $(b=-0.062 \pm 0.020)$.

Jpn. J. Zootech. Sci., 58 (3): 259-265, 1987
\end{abstract}

Key words : chimera, heterosis, body weight, mouse

Chimeric mice from embryos of two different inbred strains contain genetically different cell populations. Although their cells have the same genetic constitutions of each inbred strain, it is quite possible that a mixture of genetically different cells confers biochemical flexibility in a manner analogous to heterosis, and thus chimeric animals show "hybrid vigor"1). There is, however, little experimental evidence to support this phenomenon. MIKAMI and $\mathrm{ONISHI}^{2)}$ reported that a mean litter size of $\mathrm{C} 57 \mathrm{BL} / 6 \leftrightarrow \mathrm{BALB} / \mathrm{c}$ female chimeric mice was about $30 \%$ larger than the means of the component inbred strains. FALCONER et al. ${ }^{3)}$ examined chimeric heterosis for body weight in chimeric mice derived from strains selected for large and small size and unselected controls. Although some evidences for heterosis were offered, the authors indicated that their data were not sufficient for making definite conclusions. CRAIGVEIT and ANDERSON ${ }^{4)}$ examined reproductive performance and body weight of chimeric mice using two lines that differed in litter size. For body weight, chimeras were highly above the midparent average, while $F_{1}$ crosses were similar to the midparent average.

In this study, we confirmed chimeric heterosis for body weight at 8 weeks 
of age in $\mathrm{C} 57 \mathrm{BL} / 6 \leftrightarrow \mathrm{BALB} / \mathrm{c}$ chimeras and investigated the relationship between body weight and the relative proportions of the two cell populations in thier bodies. Female chimeras in this study were the same as those of the previous study ${ }^{2}$.

\section{Materials and Methods}

Inbred strains $\mathrm{C} 57 \mathrm{BL} / 6 \mathrm{Cr}\left(\mathrm{a} / \mathrm{a}, \mathrm{B} / \mathrm{B}, \mathrm{C} / \mathrm{C}, \mathrm{Gpi}-1^{\mathrm{a}} / \mathrm{Gpi}-\mathrm{l}^{\mathrm{a}}\right), \mathrm{BALB} / \mathrm{cCr}(\mathrm{A} / \mathrm{A}, \mathrm{b} / \mathrm{b}$, $\left.\mathrm{c} / \mathrm{c}, \mathrm{Gpi}-\mathrm{l}^{\mathrm{b}} / \mathrm{Gpi}^{\mathrm{i}} \mathrm{l}^{\mathrm{b}}\right)$ and non-inbred strain ICR were purchased from Shizuoka Agricaltual Cooperative Association for Laboratory Animals.

All chimeric mice (C $57 \mathrm{BL} / 6 \longleftrightarrow \mathrm{BALB} / \mathrm{c}$ ) in this study were obtained by aggregation methods. About half the chimeras were produced by the method of Awata et $a l .{ }^{5)}$. The other chimeras were produced by the following method. The culture medium used was modified WhitTEN's medium ${ }^{6}$. The aggregation medium used was $0.005 \%$ PHA in the culture medium. Droplets of each medium were prepared in wells of a Terasaki's microtestplate (60-wells) filled with liquid paraffin oil. Fertilized 8-16 cell stage embryos were collected from superovulated $\mathrm{C} 57 \mathrm{BL} / 6$ and $\mathrm{BALB} / \mathrm{c}$ females. After removing the zona pellucida by $0.5 \%$ pronase in Hanks' balanced salt solution, pairs of each component embryo were placed into the droplets of aggregation medium. The pairs were made to contact each other by pipetting, then the microtestplate was left for $10 \mathrm{~min}$ at $37^{\circ} \mathrm{C}$. Firmly contacted pairs were rinsed in the droplets of culture medium and cultured for about $20 \mathrm{hr}$ under an atmosphere of $5 \% \mathrm{CO}_{2}$ in air at $37^{\circ} \mathrm{C}$. After the embryos developed to morulae or blastocytes, they were transferred to pseudopregnant foster ICR mothers.

The component strains and their reciprocal $\mathrm{F}_{1}$ crosses were used as control animals. Since the mean litter size of the ICR foster mother producing chimeras was small, averaging four, control litters were standardized to four pups and nursed by an ICR dam on the day of parturition to minimize maternal effects on pup growth. Mice were weaned at 21 days of age and four mice of the same sex were caged together. Commercial pellets and water were supplied ad libitum. Temperature and relative humidity were maintained as nearly constant as possible, $23^{\circ} \mathrm{C}$ and $55 \%$, respectively. The light regime was $12 \mathrm{hr}$ of artificial illumination followed by $12 \mathrm{hr}$ of darkness. Seventy three overt chimeras and 226 controls were weighed at 8 weeks of age.

The proportion of cells from each component strain was estimated by quantitative glucose phosphate isomerase (GPI) analyses. Seventy two overt chimeras were used for GPI analyses but one female chimera could not be analyzed, since it died after being weighed at 8 weeks. Under anesthesia with pentobarbital sodium, blood was throughly withdrawn from the heart and tissue samples quickly excised. Liver, kidney, spleen, stomach, intestine, lung, heart, testis, seminal vesicle, ovary, uterus and erythrocyte were used for the analyses. One volume of washed packed erythrocytes was mixed with 5 volumes of distilled water and 1 volume of tissue sample was homogenized with 20 volumes of $50 \mathrm{mM}$ tris- $\mathrm{HCl}$ buffer, $\mathrm{pH} 7.5$, containing $1 \mathrm{mM} \beta$ mercaptoethanol and $1 \mathrm{mM}$ EDTA. The homogenate was centrifuged for $30 \mathrm{~min}$ at $10,000 \mathrm{rpm}$, and the supernatant solution was used as the emzyme source. The 
methods of electrophoresis and scanning densitometry were those of MrKAMI and $\mathrm{ONISHI}^{2)}$.

\section{Results and Discussion}

Table 1 shows a comparison of the mean body weight of chimeras at 8 weeks with those of control animals. All control litters were adjusted to four as the average litter size of delivered chimeras and were nursed by ICR dams to minimize difference in maternal effects. We neglected prenatal maternal effects, because uterine effects on pup growth in mice were important at birth and possibly at 2 weeks of age, but no important influence was noted for later weight ${ }^{7)}$. The mean body weight of $\mathrm{C} 57 \mathrm{BL} / 6$ was almost the same as that of $\mathrm{BALB} / \mathrm{c}$ and no reciprocal crossbred differences were observed. $F_{1}$ crosses were significantly $(P<0.001)$ larger than their parental strains and showed on the average $19.2 \%$ heterosis in males and $11.4 \%$ heterosis in females. The mean body weight of chimeras was also larger than that of the two inbred strains, and differences being highly significant $(\mathrm{P}<0.001)$. Then, chimeric heterosis for body weight was obvious, which was $16.4 \%$ in males and $11.9 \%$ in females. MIKAMI and $\mathrm{ONISHI}^{2)}$ reported that the mean values of heterosis for litter size in the $\mathrm{F}_{1}$ and chimeric mice were 53 and $32 \%$, respectively. The values obtained in this study were smaller than those values. EATON ${ }^{8)}$ and BUTLER ${ }^{9)}$ showed that heterosis was greater for litter size than for body weight in $F_{1}$ mice. Generally a large heterosis effect is expected for reproductive traits than for growth traits in livestocks.

Chimeric heterosis was greater for males than for females, as well as heterosis in the $\mathrm{F}_{1}$ crosses. KIDwell and HowARD ${ }^{10)}$, White et $a l .{ }^{11)}$ and BAKKer et al. ${ }^{12)}$ reported that $F_{1}$ males showed greater heterosis for body weight than $F_{1}$ females. STonAKER ${ }^{13)}$ suggested that heterosis was more closely associated with sex chromosome influence than with general sex-endocrine environment. Conversely, White et al. ${ }^{11)}$ found that

Table 1. Comparison of body weight at 8 weeks of age between chimeras and the controls

\begin{tabular}{|c|c|c|c|c|c|c|}
\hline & \multicolumn{2}{|c|}{$\begin{array}{l}\text { Number of } \\
\text { individuals }\end{array}$} & \multicolumn{2}{|c|}{ Body weight $(g)^{1)}$} & \multicolumn{2}{|c|}{ Heterosis $(\%)^{2)}$} \\
\hline & Male & Female & Male & Female & Male & Female \\
\hline \multicolumn{7}{|l|}{ Chimera } \\
\hline $\mathrm{C} 57 \mathrm{BL} / 6 \longleftrightarrow \mathrm{BALB} / \mathrm{c}$ & 42 & 31 & $31.61 \pm 0.30^{b}$ & $23.75+0.26^{\mathrm{a}}$ & 16.4 & 11.9 \\
\hline \multicolumn{7}{|l|}{$F_{1}$} \\
\hline $\mathrm{C} 57 \mathrm{BL} / 6$ 우 × $\mathrm{BALB} / \mathrm{c}\}$ & 32 & 25 & $32.65 \pm 0.35^{a}$ & $23.46 \pm 0.33^{\mathrm{a}}$ & 20.2 & 10.6 \\
\hline $\mathrm{BALB} / \mathrm{c}$ 우 $\times \mathrm{C} 57 \mathrm{BL} / 6$ 웅 & 31 & 25 & $32.13 \pm 0.35^{\mathrm{ab}}$ & $23.82 \pm 0.24^{\mathrm{a}}$ & 18.3 & 12.3 \\
\hline C $57 \mathrm{BL} / 6$ & 31 & 25 & $27.27 \pm 0.23^{c}$ & $21.44 \pm 0.24^{\mathrm{c}}$ & & \\
\hline $\mathrm{BALB} / \mathrm{c}$ & 32 & 25 & $27.07 \pm 0.26^{c}$ & $21.00 \pm 0.21^{c}$ & & \\
\hline
\end{tabular}

1): Mean \pm S.E.

2): $\left[\left(\right.\right.$ Chimera or $\left.\left.F_{1}-\bar{p}\right) / \bar{p}\right] \times 100$, where $\bar{p}=($ C $57 \mathrm{BL} / 6+\mathrm{BALB} / \mathrm{c}) / 2$.

$\mathrm{a}, \mathrm{b}, \mathrm{c}:$ In the same column with different letters differ significantly; a and $\mathrm{c}, \mathrm{P}<0.001$; b, $\quad \mathrm{P}<0.05$. 
sex-linkage had little influence on growth and sex-heterosis interactions were significant in only postweaning traits which were measured at or after sexual maturity. However, precise answer to the cause could not be answered in this study.

Table 2 shows the mean proportions of cells from $\mathrm{C} 57 \mathrm{BL} / 6$ in the organs, estimated by quantitative GPI analyses. There were no sex differences in the mean cell proportions. The slight low percentage of $\mathrm{C} 57 \mathrm{BL} / 6$ cells was observed in all organs except for spleen. When the average of proportions for all organs was taken, the mean of the $\mathrm{C} 57 \mathrm{BL} / 6$ cell population was $41.7 \%$ in males and $41.8 \%$ in females. This result suggests that some predominate selection of $B A L B / c$ cell occurred in chimeric tissue growth. Gearhart and Oster-Granite ${ }^{14)}$ found that BALB/cByJ component frequently predominate in $\mathrm{BALB} / \mathrm{cBy} \mathrm{J} \leftrightarrow \mathrm{C} 57 \mathrm{BL} / 6 \mathrm{~J}$ chimeras.

Fig. 1 shows the relationship between body weight and mean cell proportion of C $57 \mathrm{BL} / 6$ component in 10 organs of male and female chimeras. Chimeras with a high degree of chimerism, about $50 \%$ cell proportion, showed large body size. The linear regressions of body weight on chimerism are shown in Fig. 2, where deviation from the $50 \%$ of $\mathrm{C} 57 \mathrm{BL} / 6$ component was used as a measure of chimerism. The regressions were statistically significant in males $(b=-0.083 \pm 0.019, P<0.01)$ and in females $(b=-0.062 \pm 0.020, P<0.01)$ and thus, it is obvious that the body weight of chimeras is linearly related to the degree of chimerism in the body.

CRAIG-VeIt and ANDERSON ${ }^{4)}$ examined reproductive performance and body weight of female chimeras using two lines, JU and $\mathrm{C}$ line. JU line was significantly larger than $\mathrm{C}$ line in litter size and body weight. For most reproductive traits, $\mathrm{F}_{1}$ crosses and chimeras were similar, regardless of whether the means were at or above the midparent average. In contrast, for ovulation rate and body weight, $\mathrm{F}_{1}$ crosses and chimeras clearly differed, with chimeras being similar to the JU line and $F_{1}$ crosses

Table 2. Mean cell proportions of C $57 \mathrm{BL} / 6$ in 10 organs of chimeras

\begin{tabular}{llc}
\hline \hline \multirow{2}{*}{ Organ } & \multicolumn{2}{c}{$\%$ C 57 BL/6 \pm S.E. } \\
\cline { 2 - 3 } & \multicolumn{1}{c}{ Male } & Female \\
\hline Liver & $41.4 \pm 3.7(42)^{*}$ & $42.7 \pm 5.2(30)$ \\
Kidney & $37.9 \pm 3.3(42)$ & $41.7 \pm 4.5(30)$ \\
Spleen & $54.5 \pm 3.0(42)$ & $53.3 \pm 3.7(30)$ \\
Stomach & $36.2 \pm 3.2(42)$ & $37.6 \pm 4.3(30)$ \\
Intestine & $35.3 \pm 3.1(42)$ & $38.3 \pm 4.3(30)$ \\
Lung & $42.6 \pm 3.3(42)$ & $43.0 \pm 4.4(30)$ \\
Heart & $39.5 \pm 3.2(42)$ & $38.0 \pm 3.8(30)$ \\
Erythrocyte & $45.0 \pm 3.7(41)$ & $43.4 \pm 5.0(25)$ \\
Testis & $45.6 \pm 5.0(42)$ & \\
Seminal vesicle & $39.0 \pm 4.0(42)$ & \\
Ovary & & $38.9 \pm 4.7(28)$ \\
Uterus & & $41.3 \pm 4.1(29)$ \\
Mean & $41.7 \pm 1.2(419)$ & $41.8 \pm 1.4(292)$ \\
\hline
\end{tabular}

* : Number of organs 
Chimeric Heterosis for Body Weight in Mice

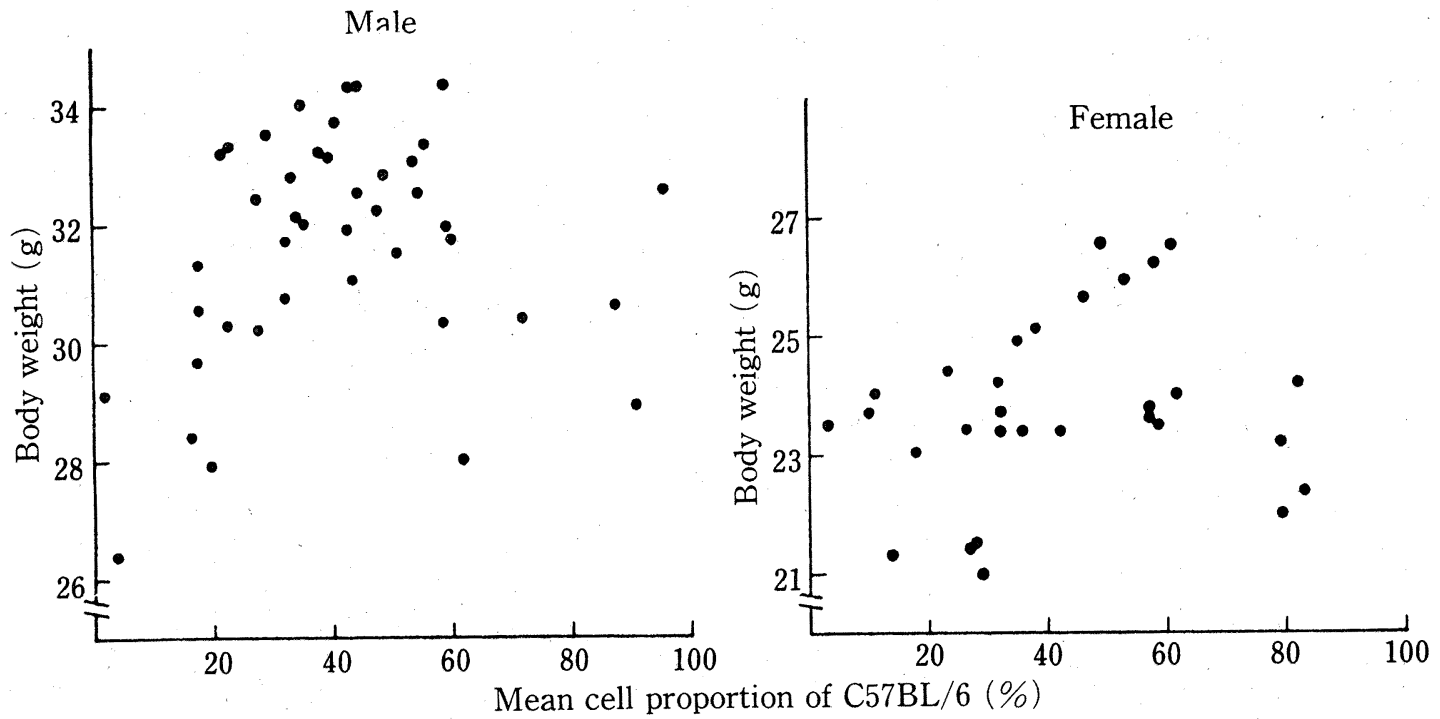

Fig. 1. Relationship between body weight and the degree of chimerism in 10 organs of male and female chimeras. The mean cell proportion of $\mathrm{C} 57$ $\mathrm{BL} / 6$ was used as a measure of the degree of chimerism, $50 \%$ thus indicating the highest chimerism.

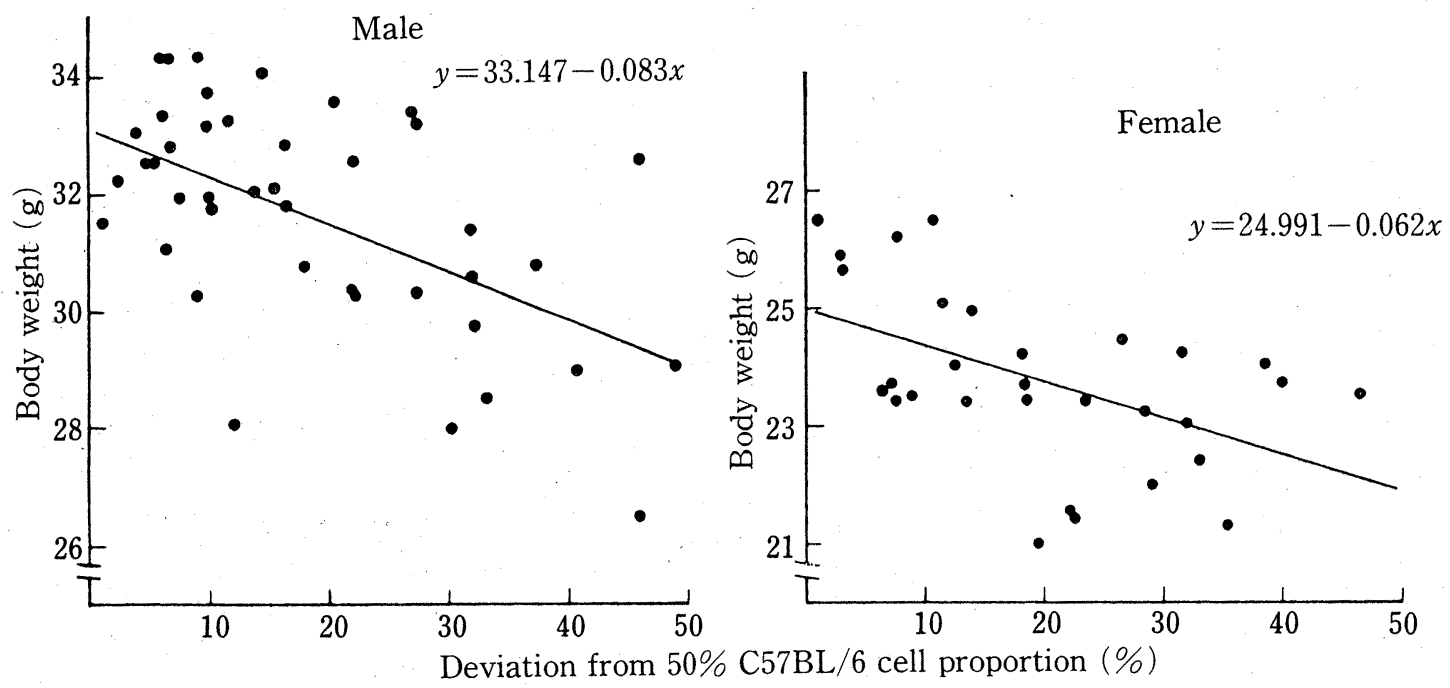

Fig. 2. Relationship between body weight and the degree of chimerism in 10 organs of male and female chimeras. The deviation from $50 \%$ C $57 \mathrm{BL} / 6$ cell proportion was used as a measure of the degree of chimerism, $0 \%$ thus indicating the highest chimerism.

being at the midparent average. They suggested that presence of a critical proportion of JU cells would permit threshold of some factors of body weight or ovulation rate to be reached, overriding any regulatory influence of $\mathrm{C}$ line cells. However, the relation of cell proportion to body weight or to ovulation rate was not examined. FALConer et al. ${ }^{3)}$ found that body weight was strongly influenced by mean cell proportions in 


\section{ONISHI and MIKAMI}

chimeras derived from strains differing in body weight. Their $F_{1}$ crosses showed about $12 \%$ heterosis for body weight at 6 weeks and chimeras also showed some heterosis effects. In the present study, the mean body weights of the two parental strains were almost equal and $F_{1}$ crosses and chimeras were significantly larger than both parental strains. The chimeric individuals varied widely in their mean cell proportions and the degree of chimerism was positively correlated with body weight. These results indicated that the presence of genetically different cells in one individual confers rapid growth. In chimeras, certain metabolic functions may be expected to be enhanced over those of inbred parents, because chimeras contain two distinct types of gene products (e. g., enzyme) which would work complementarily to increase their activities and stabilities. However, it is not possible to say from this work whether chimeric heterosis has a common mechanism involved in heterosis in $F_{1}$ crosses. Further biochemical studies on this probrem are necessary.

\section{References}

1) McLaren, A., In Mammalian chimaeras. 133. Cambridge University Press. Cambridge, London. 1976.

2) Mikami, H. and A. Onishi, Genet. Res., 46:85-94. 1985.

3) Falconer, D.S., I.K. Gauld., R.C. Roberts and D.A. Williams, Genet. Res., $38: 25-$ 46. 1981.

4) Craig--Veit, C. and G.B. Anderson, J. Anim. Sci., 61 : 1527-1538. 1985.

5) Awata, T., A. Onishi and S. Muramatsu, Proc. Japan Acad., 60 (B) : 253-256. 1984.

6) Hoppe, P.C. and S. Pitts, Biol. Reprod., $8: 420-426.1973$.

7) Legates, J.E., J. Anim. Sci., 35:1294-1302. 1972.

8) Eaton, O.N., Genetics., $38: 609-629.1953$.

9) Butler, L., Can. J. Zool., $36: 969-983.1958$.

10) Kidwell, J.F. and A. Howard, Growth., 33:269-289. 1969.

11). White, J.M., E.J. Eisen and J.E. Legates, J. Anim. Sci., 31 : 289-295. 1970.

12) Bakker, H., J. Nagai and E.J. Eisen, J. Anim. Sci., $43:$ 1145-1155. 1976.

13) Stonaker, H.H., J. Anim. Sci., $22: 320-325.1963$.

14) Gearhart, J. and M.L. Oster-Granite, Biol. Reprod., $24: 713-722.1981$. 
Chimeric Heterosis for Body Weight in Mice

マらスの体重に拈けるキメラ性へテローシス

大西 彰・三上仁志

農林水産省畜産試験場，茨城県筑波農林研究団地 305

マウスの体重にキメラ性へテローシスが発現するかど うかを確認し，さらにキメラ性へテローシスと体を構成 している 2 種類の細胞群の割合との関連性について検討 した. C $57 \mathrm{BL} / 6$ 胚と BALB/c 胚を用いて作出した凝 集キメラマウスとコントロール群, C 57 BL/6, BALB/ $\mathrm{c}$ およびそれらの相反交雑 $\mathrm{F}_{1}$ を供試し，それらの体重 を 8 週齢時に測定した. キメラの平均体重は有意に両近 交系よりあ大きく, キメラの体重にキメラ性へテローシ スが発現することが明らかとなった．キメラ性へテロー シスは雄で $16.4 \%$, 雌で $11.9 \%$ であった. 相反交雑間
で平均した $\mathrm{F}_{1}$ のヘテローシスは雄で $19.3 \%$, 雌で $11.5 \%$ であった. キメラを構成する各系統由来の細胞 群の割合は定量的 GPI 分析によって 10 種類の臓器(肝 臓, 腎臓, 脾臟, 胃, 腸, 肺, 心臓, 赤血球, 精巣また は卵巣，精囊腺または子宮）を用いて推定した。臓器の 平均細胞割合では $\mathrm{BALB} / \mathrm{c}$ 細胞の割合がやや高い值を 示した. キメラの体重とキメラの割合との間には有意な 直線的関係がみられ, 雄で $b=-0.083 \pm 0.019$, 雌で $b$ $=-0.062 \pm 0.020$ の回帰係数がそれぞれ得られた.

日畜会報， $58 （ 3 ） ： 259-265,1987$ 